\title{
Effect of Employee Welfare Facilities on Employee Retention: A Study of Cabin Crew Employees in Sri Lankan Airlines
}

\author{
M. D. R. Harshani ${ }^{1}$ and I. Welmilla ${ }^{2}$ \\ ${ }^{1,2}$ Department of Human Resource Management, Faculty of Commerce and \\ Management Studies, University of Kelaniya, Sri Lanka \\ 2iwelmilla@kln.ac.lk \\ D https://orcid.org/0000-0003-1705-0779
}

\begin{abstract}
The employee welfare facilities are recognized as one of a prominent Human Resource Management section in current world. This study is to discuss the effect of employee welfare facilities on cabin crew employee retention in Sri Lankan Airlines. The main objective of the study was to examine the effect of Employee Welfare Benefits to the Retention of the Employees among Cabin Crew Employees in Sri Lankan Airlines. To achieve this objective two hypotheses were developed and tested. The independent variable and the dependent variable of the study was welfare facilities and employee retention respectively. The validity and reliability of the instruments was tested by using Cronbach's Alpha and test-retest methods. The type of this study is hypothesis testing and it was conducted in the natural setting with less interference of the researcher. The study is a cross-sectional in time and the primary data was collected by using random sampling technique and sample size was 40 cabin crew employees who are working in Sri Lankan Airlines. The unit analysis was at individual level. Data was collected through a structured questionnaire. The offline method was used to gather the data and the primary data set was used. The correlation and regressions methods were performed to test hypotheses and analyzed data.

Findings of the study reveal that employee welfare facilities positively and significantly effect on employee retention and there is a positive strong relationship between employee welfare facilities and employee retention. As a significant factor, welfare facilities should be enriched by the management to get the maximum benefits from the employees.
\end{abstract}

Keywords: Employee Welfare Facilities, Employee Retention, Cabin Crew Employees 


\section{Introduction}

Human resource is the most valuable asset to an organization. Because it is the only resource which can think independently, act independently. Core employees make the difference and they are basic for the firm in order to reach their objectives (Balk in \&Bannister, 1993; Gomez-Mejia \& Balkin, 1992) as in (Kossivi, Xu \& Kalgora, 2016). Further human being is innovative, creative, unique, and communicative. It can take decisions independently, with a presenting ability and further it is the only resource which can control other resources within the organization towards the goals.

The workers are able to develop capacities to respond to the changing requirements of the firms, thus becoming a highly valuable resource. Advancement in technology has caused most organizations to be more and more technology driven. However, this situation does not reduce the value of employees in an organization because technology requires human resources to operate.

Social developments such as continuing globalization, technological innovation, and growing global competition place pressure on companies and emphasize their need to maintain their competitive edge (Burke \& Ng 2006) as in (Kyndt, Dochy, Michielsen \& Moeyaert , 2009) at least in part through maintaining the skills of their employees.

The keyword in terms of human resource management is retention (Mandhanya, 2016). It is "holding, maintaining, continuation, and preventing from leaving". It means, securing employees in a company. Efficient human resource practices are the base for retention of employees in any organization (Mandhanya, 2016).

Organizations spend considerable time effort and money to train an employee into a valuable asset and to leave the company for a greener pasture within the industry (Mandhanya, 2016).

The toughest challenge that organizations encounter nowadays is not only how to manage the people but also how to keep them on the job as long as possible and how to maintain them vigorous and ambitious (Kossivi, $\mathrm{Xu}, \&$ Kalgora, 2016). Securing and retaining skilled employees plays an important role in the organizational process, because employees' "knowledge and 
skills" are central to companies' ability to be economically competitive" (Kyndt, Dochy, Michielsen, \& Moeyaert, 2009). Further given that employee retention is very important for the functioning and competitiveness of a company (Kyndt, Dochy, Michielsen, \& Moeyaert, 2009).

Hiring good people is tough, but keeping them can be even tougher. In this dynamic environment opportunities are ample which motivates the employees to leave (Mandhanya, 2016). Therefore it's hard to retain the talents within the organization Offering competitive employee benefits is what will set one business apart from another and will attract and retain valuable employees. (Mandhanya, 2016)

To remain more competitive, organizations need therefore not to only attract the best talents but also to retain them on the job for a long term (Mandhanya, 2016).

There are various practices followed by different organizations to retain their employees. But important among them is the compensation and the benefit packages providing to its employees. According to (Watson \& Wyatt's, 2006) Strategic Rewards study, 22 percent of top-performing employees cited benefits as one of the top three reasons they would leave their employer as in (Mandhanya, 2016) .

Retention of good employees is a valuable part of the success of any organization (Premarathna \& Perera, 2015) through a goal to fulfill human needs and upgrade standards of the lives of their people, organizations achieve its organizational goals and objectives. Today the service sector is playing a vital role in Sri Lankan Economy. In service industry, where there are no production lines, people are the most important asset to the organization (Sanes, 1996). The service delivering to the customers are totally depend on its employees within the organization.

Organizational asset and everything depends on how the employees work as part of a team. This means that, to get the best results, managers have to care about how they (the employees) live and function, not just about how they work and produce (Boyd, 2001) as in (Marshall, 1984). Money benefits and different forms of compensation have been used to attract retain and motivate employees and achieve organizational goals of the organizations around the world. (Barber \& Bretz, 2000; Chuietal, 2001; Lasear, 1998; Milkovich \& 
Newman, 1999; Raynes \& Gerhart, 2000; Tang et, 1998, 2000 a,b) as in ( Randy \& Chui, 2002 ).

According to (Randy \& Chui, 2002) as a result of providing welfare benefits to the employees apart from the direct wages and salaries, the employers enjoy a rather stable and loyal workforce.

Welfare benefits such as insurance or pensions typically lower turnover. The fringe benefit indicator takes a value equal to one if the individual receives either employer provided insurance (medical, dental, and life), maternity leave, firm sponsored training and education, or employer-provided child care (O'Halloran, 2012). After going through the literature a need arises to research whether the welfare benefits of cabin crew employees in Sri Lankan Air Lines having any effect on the job retention, because the industry of airline and cabin crews are provided variety of benefits apart from the direct wages and salaries

This study is aimed to discuss the welfare facilities and its impact to the decisions of employee retention.

\section{Problem Statement}

Due to the new global shift, the economy has already shifted from agricultural sector to industrial and service sector. As a result of that service and industrial sectors have become more complex and competitive. When considering the service sector, companies operated under this context are now struggling to survive not only within the domestic market but also within the international market (Gleave, 2015). Companies within the service sector have to produce its services as superior outcomes such as high quality customer services, innovation, new technological methods for delivering the service in a quality way, new management concepts etc...

To maintain their image within a competitive business environment. To have this kind of superior outcomes it is essential for them to manage high skilled and talented human resource within their organizations. Though it is well known fact that managing human resources within an organization is not an easy or simplest task. To achieve superior outcomes through human resources it is important to have the valuable employees loyal and it is important to retain them within the organization. 
However, when considering service sector in Sri Lanka, poor employee retention practices have become a more common and crucial problem behind inefficient outcomes such as low quality service deliveries, less innovation, employee dissatisfaction, turnover, absenteeism etc.

Researchers have found several reasons for employee retention such as compensation and appreciation of the performed work, provision of challenging work, chances to be promoted and to learn, invitational atmosphere within the organization, positive relations with colleagues, a healthy balance between the professional and personal life, and good communications etc...among them most of the researchers revealed employee compensation and employee benefits and as one of major predictor of employee retention. Other researchers have suggested that remuneration is the key to retention in the service industry (Horgan 1992) as in (Premarathna \& Perera, 2015).

Turnover is becoming a major problem of cabin crew employees within the Airline Industry of Sri Lank. Due to its long hour working schedules without a rest, life risk associated with the employment, problems regarding with the emotional and esthetic labour conditions and problems which are arising regarding to the work life balance of the cabin crew employees (Gleave, 2015).

Flight attendants are the most visible of airline employees, but they do lots more than just serve drinks. That's what lot of people think. Flight attendants are responsible for everyone on the plane, including their general safety and evacuation procedures. They go through a lot of rigorous training and put in a lot of unseen hard work.

Due to the nature of the occupation of cabin crew employees their work schedules, long hour service shifts, risk associated with the employment and the threats towards their health and unbalance between their career and personnel life leads to make them away from their job and finally to withdrew from the organization.

Though these employees are treated with a variety of benefits other than any occupation, Some employees who are currently working and who are already withdrew from the company revealed that sometimes the existing welfare benefits are not sufficient with their working load. It reveals there is a gap 
between the existing employee benefits which are already giving to them and the real need from side of employees.

Thus it create a need to identify whether the existing variety of employee benefits are affect to the decision of retention within the organization. Because it is a large investment from the company's view. Researcher observed poor employee benefits towards the employees as a one of major reason behind the turnover of cabin crew employees. Therefore researchers selected this work setting for the current study

Welfare facilities can be considered as a method of improving retention in the organization (Premarathna \& Perera, 2015). And also it is important to mention that though previous researches were focused on the same relationship between employee welfare benefits and employee retention. Their findings were complying with other previous researches. Similarly it is important to mention that above all studies have been done in the western context as well as in the Sri Lankan context in different industries and very specifically in service organizations. Because of that it's better to conduct such a research in a different industry of Airlines in Sri Lanka. Based on that aim, following research problem was constructed to carry out this study.

\section{What is the relationship between welfare benefits and retention of employees in Sri Lankan Airlines?}

\section{Objectives of the Study}

Main objective of the study is to examine whether welfare facilities effect on retention of cabin crew employees in Sri Lankan Airlines. Further, the specific objectives of the study are:

i. To identify whether there is a relationship between welfare facilities and employee retention of cabin crew employees in Sri Lankan Airlines.

ii. To identify the impact of welfare facilities on the employee retention of cabin crew employees in Sri Lankan Airlines. 


\section{Literature Review}

Human Resource Management (HRM) is the efficient and effective utilization of human resources to achieve goals of an organization (Opatha, 2002) as in (Premarathna \& Perera, 2015). Moreover Human Resource Management is dealing with attracting and retaining best people to the organization (Premarathna \& Perera, 2015). Today Human Resource Management is a very significant functional field of organizational management. Managing human resources in an organization is very important towards achieving organizational goals and objectives (Opatha, 2002) as in (Premarathna \& Perera, 2015).

Due to the impact of development in the world economy, most of the countries are now sustained with different level of employment sectors. When considering Sri Lankan context, service sector has become one of major contributor to the Sri Lankan economy. In a service sector of employment, human recourse plays very important role because it is the only resource that can be used to achieve competitive advantages. Employees are the most valuable assets of an organization. Their significance to organizations calls for not only the need to attract the best talents but also the necessity to retain them for a long term (Kossivi, Xu, \& Kalgora, 2016).

Employees have been important resources to any organization. Based on their critical characters, they can be termed as the life-blood of an organization (Kossivi, Xu, \& Kalgora, 2016). Moreover human resource is the most important factors of production in each and every industry, both in goods and service manufacturing.

Employees' knowledge, skills, and abilities have become a critical strategic variable in the development and maintenance of firm's competitive advantages (Porter, 2001) as in (Vidal-Salazar, Cordón-Pozo, \& Torre-Ruiz, 2016). Human resource is the only resource which can create a competitive advantage for and organization within the industry or within the market.

Achievement of the organizational goals and objectives are totally depending on its human resource within an organization. Because the workforce is the body of the organization which control and direct the other resources towards to the achievement of the organizational goals. The human resource possesses skills, experience, and knowledge that add economic value to firms or 
organizations. Research with small, medium, and large businesses from around the world has found that employee benefit and compensation packages can play a strategic role in employee retention, enhancing organizational performance and profitability (Joo, 2000; Mangel and Useem, 2000; Meyer et al., 2001) as in (Carraher, 2011).

Compensation can be defined as the combination of pay and rewards to employees (Ahmad \& Scott, 2015). While pay refers to direct financial payments such as salaries, bonuses, incentives and commissions, reward refers to indirect payment or fringe benefits. Compensation is the most important factor favoring employee retention (Mandhanya, 2016). Compensation might not be the most important factor in determining whether an employee will stay with a particular organization. But it can tip the balance.

According to the social exchange theory views an employment relationship consists with social or economic exchanges (David. \& Robert, 2007) as in (Mutiria, Rukangu, \& Kubaison, 2015). Economic exchange relationships involve the exchange of economic benefits in return for employee efforts. Social exchanges are "voluntary actions" which may be initiated by an organization's treatment of its employees, with the expectation that the employees will be obligated to reciprocate the good deeds of the organization. The exchange approach view that individuals attach themselves to their organizations in return for certain rewards and benefits from the organization, failure by the organization to provide sufficient rewards in exchange for employeese efforts, is likely to result in decreased organizational engagement.

According to the exchange perspective, employees exchange their identification, loyalty and attachment to the organization, in return for incentives and benefits from the organization. If employees feel supported and their goals and career advancement looked into, their intention to stay will be higher.

Today most organizations trying to "win the hearts and minds of employees" by adopting a caring approach to managing its people due to the active cooperation and commitment of employees is a valuable resource offering the key to achieving a competitive edge. Compensation provided to employees is a critical tool for human resource managers to attract, motivate and retain 
skilled workers (Hayes \& Ninemeier, 2008) as in (Ahmad \& Scott, 2015). Employee benefits of Japanese organizations have been a central concept, just as important as training and development, in the retention management (Yamamoto, 2011) as in (Premarathna \& Perera, 2015).

According to (Mitchell,1982) as in (Premarathna \& Perera, 2015) explained that effective selection and recognition of employee, provision of effective training, challenging emplacement structures and opportunities, equity of compensation and benefits were considered to be the top five human resources practices that were considered to be relevant for retention. Therefore, the welfare facilities are mainly important to retain the workforce of the organization in the organizational strategic direction.

However, these studies examined the relationship among the employee welfare benefits and employee retention. This study further discussed different aspects posed by the researches on the employee retention and employee welfare benefits. According to previous studies the welfare facilities are mainly important to retain the workforce of the organization towards the organizational strategic direction. This study is aimed to discuss the welfare benefits and its impact to the decisions of employee retention.

\section{Conceptual Framework}

The conceptual framework of the study is given in Figure 01. According to the diagram shown in Figure 01, employee retention is considered as the dependent variable. Welfare facilities are considered as the independent variables as it is assumed to have influence on employee retention. In Japanese organizations, together with training and development, employee benefit management has been emphasized as a sub - System in Human resource management conducive to employee retention (Yamamoto, 2011).

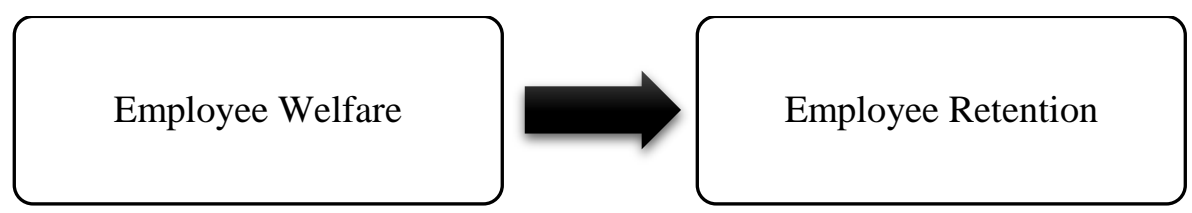

Figure 01: Conceptual Framework of the Study

Source: Author, 2017 
Quality employee facilities are rarely portable and it is only natural for employees to stay for long periods of time at organizations providing good benefits (Premarathna \& Perera, 2015). Previous studies have shown that employee benefit practices, if not all practices, have a certain positive effect on retention (Mitchell, 1982).

In this research, the employee welfare facilities has been taken as independent variable and assumed that these variables has a relationship with employee retention based on the Diminishing sensitivity effect, Endowment effect, and Framing effect. These three effects explain the attachment towards the welfare benefits by employees in the decision of retaining with the employer than the monetary wages.

Diminishing sensitivity is a characteristic of human nature (Kahneman and Tversky, 1979), correspondingly according to (Olsen, 2002) that is singling out the fringe benefit component. Employees may experience the value as larger than a similar incremental in money wages.

Endowment effects (Thaler, 1980; Kahneman, Knetsch and Thaler, 1990) as citied in (Olsen, 2002) may make some employees more attached to fringe benefits than the equivalence in money. Framing effects (Tversky and Kahneman, 1986; Kahneman, Knetsch and Thaler, 1990) as citied in (Olsen, 2002) may affect employeese evaluation of fringe benefits compared to money wages

In this research, welfare facilities (Example: health insurance, retirement plan, training, travel perks, compressed work schedules and food and housing) considered as the independent variable and assumed that the variable, have a certain positive effect on retention relationship with the employee retention based on the research evidence in the international research studies (Mitchell, 1982) as in (Premarathna \& Perera, 2015).

Employee welfare facilities can be introduced as an important function of HRM. It has become an important factor of the employment contract. Employee welfare can be defined as providing facilities and comforts to employees of an organization. They will be able to lead a better level of living (GDN, 2015) as in (Opatha, 2002). It has become the core of any employment exchange (Bloom \& Milkovich, 1996). In this research, welfare facilities (health insurance, retirement plan, training, 
travel perks, compressed work schedules and food and housing) considered as the dimensions to be tested in the independent variable.

Organizations today are at greater risk of losing capable human resources to the in organizations. According to (Yamamoto, 2011) the retention is holding, maintaining, continuation, and preventing from leaving,

It is securing employees in a company. In the retention concept, organizations are the key players and retention is a specific organizational management issue, namely, retention management, which can be defined as, the entire human resource management policies for retaining the current or expected high performing employees within organizations for long period of time, enabling them to exercise or develop their capabilities (Yamamoto, 2009) as in (Yamamoto, 2011).

As mentioned in above the effective employee retention is a systematic effort by employers to create and foster an environment that encourages current employees to remain employed by having policies and practices in place that address their diverse needs (Wisconsin State Government, 2005) as in (Premarathna \& Perera, 2015).

Employee retention refers to the ability of an organization to retain its employees. It relates to the efforts by which employers attempt to retain employees in their workforce. Further employee retention is adopting measures to prevent valuable employees from leaving their occupation (Premarathna \& Perera, 2015). The employee retention can be occurred due to various reasons and the welfare facilities can be a one reason to the decision of retention within the organization (Premarathna \& Perera, 2015). The current study employee retention considered as a dependent variable.

Based on the above conceptual framework following alternative hypotheses have been advanced for the study.

$\mathrm{H}_{1}$ : $\quad$ There is a significant relationship between welfare facilities and employee retention of cabin crew employees in Sri Lankan Airlines.

$\boldsymbol{H}_{2}$ : $\quad$ There is a significant impact on employee welfare facilities to employee retention of cabin crew employees in Sri Lankan Airlines. 


\section{Methods}

The main objective of this study was to investigate the relationship between the welfare facilities and the employee retention in cabin crew employees in Sri Lankan Airlines and the hypotheses was developed based on this objective. The study was conducted by using a sample of 40 cabin crew employees in Sri Lankan Airlines which is located in Katunayake. The sample method of the survey was the simple random sampling. The current study was quantitative and a cross-sectional field study survey design was followed. Data was collected through a structured questionnaire. The offline method was use to gather the data and the primary data set was used. The sample consisted of 40 cabin crew employees in Sri Lankan Airlines. The total population was 100 cabin crew employees and the sample of 40 cabin crew employees was selected due to the ability available with the sample size of 40 to generalize the findings of the study. The correlation and regressions methods were used to analyze the gathered data.

\section{Measures}

The variables in the research model such as welfare facilities and employee retention were measured through a questionnaire with five point scales which were completed by the respondents themselves on their experiences. The research consists of one independent and a one dependent variable. The questionnaire consists of a number of question items to measure these variables. The employee intention to retain was measured by using the standard questionnaire which was developed in (Kyndt, Dochy, Michielsen \& Moeyaert, 2009). It equipped the level of agreement type questions employee intention to retain. As a whole there were 11 questions. The employee welfare benefits will be measured by using the standard questionnaire of a study on employee welfare measures in (Suresha, 2007). It is a 05-item scale that addresses the level of agreement toward various employee welfare facilities: (1) health and retirement plans, (2) training, (3) travelling perks, (4) compressed work schedules and 5) food and housing. 


\section{Reliability and Validity}

The consistency reliability was examined with Cronbach's Alpha test. The results of Cronbach's alpha test are given in table 01, which suggests that the reliability of each variable is at a satisfactory level.

Table 01: Reliability Statistics

\begin{tabular}{|l|l|}
\hline \multicolumn{1}{|c|}{ Instrument } & Cronbach's Alpha \\
\hline Employee Welfare Benefits & 0.781 \\
\hline Employee Retention & 0.938 \\
\hline
\end{tabular}

The construct validity of the variables of the study was ensured by the fact that the correlation and regression analysis support the hypotheses formulated linking the relationship between the independent variable and the dependent variable.

\section{Techniques of Data Analysis}

After gathering the data it was analyzed by using the computer based statistical data analysis package, SPSS (version 23.0) for validity, reliability, the relationship testing. Correlation and regression analysis were applied in data analysis.

\section{Results}

As indicated by table 2, the mean value of the distribution of respondents is 4.1625 mean value of the distribution is "Good". The Skewness and Kurtosis of distribution are -896 and 0.946, which indicated that the data record for the employee retention is approximately normally distributed. 
Table 02: Statistics of the Distribution of Employee Retention

\begin{tabular}{|l|l|}
\hline \multicolumn{1}{|c|}{ Retention } & \\
\hline N & 40 \\
Valid & 0 \\
\hline Mean & 4.1625 \\
\hline Std. Error of Mean & 0.08034 \\
\hline Median & 4.2500 \\
\hline Mode & 4.50 \\
\hline Std. Deviation & 0.50811 \\
\hline Variance & 0.258 \\
\hline Skewness & -0.896 \\
\hline Std. Error of Skewness & 0.374 \\
\hline Kurtosis & 0.946 \\
\hline Std. Error of Kurtosis & 0.733 \\
\hline Minimum & 2.60 \\
\hline Maximum & 5.00 \\
\hline
\end{tabular}

In order to test the hypothesis the Pearson Correlation Technique was used. Correlation coefficient is significant at 0.01 level as sig (2- tailed) is less than 0.01 ; which is 0.000 . Hence, based on the test result $\mathrm{H} 1$ could be accepted and it could be concluded that there is a significant relationship between employee welfare benefits and retention intention of employees.

In order to test the impact of employee welfare benefits to employee retention the regression analysis was used. According to the results of regression analysis the $b$ value of the equation, the gradient of the regression, is 0.960 , which is significant at $1 \%$ (significance $=.000$ ) based on the test result $\mathrm{H} 2$ could be accepted and it could be concluded that there is an impact of employee welfare benefits to employee retention

The Bivariate analysis and the two tailed test was used to measure the relationship because the hypothesis is non-directional which indicates the significant relationship between the welfare facilities and the retention of cabin crew employees in Sri Lankan Airlines. Further there is statistical 
evidence to that Employee Welfare benefits and Employee Retention are positively related. Table 03 presents the results of the correlation test.

Table 3: Correlation of the Variables Employee Welfare Benefits

\begin{tabular}{|l|c|}
\hline & Employee Welfare Benefits \\
\hline Pearson Correlation & 0.757 \\
\hline Sig (2 Tailed) & 0.000 \\
\hline
\end{tabular}

Pearson Correlation between the two variables of Cabin Crew employees are 0.757 which is positive. It shows that there are positive relationship between employee welfare benefits and employee retention. The found relationship is statistically significant as correlation it's significant at 0.01 level (2 - tailed). Thus there is a statistical evidence to that employee welfare facilities and employee retention are positively related.

Table 04: Results of Regression Analysis

\begin{tabular}{|l|l|}
\hline Variable & Employee Welfare Benefits \\
\hline Method & Liner \\
\hline R square & 0.573 \\
\hline Adjusted R Square & 0.562 \\
\hline F & 51.047 \\
\hline Significance & 0.000 \\
\hline B -Constant & -0.518 \\
\hline b value & 0.960 \\
\hline
\end{tabular}

The $b$ value of the equation, the gradient of the regression, is 0.960 , which is significant at $1 \%$ (significance $=.000$ ). As indicated by R squared, $56.2 \%$ of the variance of retention is explained by employee welfare benefits with the standardized beta of 0.573 . The $F$ value is 51.047 , which is significant at $1 \%$ $(p=0.000)$, which suggest that employee welfare benefits has significantly explained $56.2 \%$ of the variance of employee retention. 
Table 5: ANOVA

\begin{tabular}{|l|l|l|l|l|l|}
\hline \multicolumn{1}{|c|}{ Model } & \multicolumn{1}{|c|}{$\begin{array}{c}\text { Sum of } \\
\text { Squares }\end{array}$} & \multicolumn{1}{|c|}{ Df } & $\begin{array}{c}\text { Mean } \\
\text { Square }\end{array}$ & F & Sig \\
\hline Regression & 9.286 & 1 & 9.286 & 51.047 & $.000^{\mathrm{b}}$ \\
\hline Residual & 6.912 & 38 & .182 & & \\
\hline Total & 16.198 & 39 & & & \\
\hline
\end{tabular}

The ANOVA table gives results of analysis of variance. Since the p value is less than 0.01 and 0.05 it is significant at both the levels of significance.it is conclude that all the model coefficient differ significantly from zero and Employee Welfare Benefits can be used to judge the retention of Employees.

\section{Implications}

The findings of the current research study will be important on the theoretical as well as the practical implications. This research model proves to be an explanatory model of employees' retention, the findings of the study are important to improve employee retention of the cabin crew employees through improving and enhancing the existing employee benefit schemes in Sri Lankan Airlines. Though they are having a high life risk and a compressed work schedule with the employment contract it is important to give them an opportunity to participate for the decision making when deciding on their real needs.

\section{Recommendations}

As an important way of enhancing the employee retention of cabin crew employees of Sri Lankan Airlines, relevant welfare facilities should be given and the enhancement of the welfare facilities are important. Leaves, allowances for medical treatments, appropriate rest breaks, fair assignments of the hours of work and with appropriate rest breaks and allowances for health and life insurances are the ways of upgrading the employee retention of cabin crew employees. 
The top management of the company should consider these factors and enhance employee retention of the cabin crew employees to gain the maximum contribution to achieve the organizational objectives.

To increase the employee retention of cabin crew employees the organization should create a positive and a working environment within the working premises. An upbeat workplace is a necessity for enhancing employee retention.

Positive competitive benefits are another significant way of enhancing retention of cabin crew employees. Because the competition is between the foreign airlines and Sri Lankan airlines employees, because it is the only major airline operates in domestic level.

Fair wages are important, but competitive benefits are also critical to keep the workforce retained. If the benefit packages are thin, employees may look for other opportunities with foreign airlines that are more generous. Beyond insurance, benefits such as flex time, paid holidays and personal days are important factors to employee retention. As the significant factor welfare facilities should be enriched by the management to get the maximum benefits of the employees.

\section{Limitations}

The sample size was slight narrow and according to the time limitation the researcher couldn't able to reach a broader sample. It is recommended to future researches to take time and reach to a larger sample.

It was a one major limitation on focusing only a one airline company operating in Sri Lanka. It is the only airline operates in Sri Lanka as a competitive firm to the global airlines. It is Due to the difficulty of time availability, less financial resources, access restrictions from the Airline Operations and less contacts with the other foreign Airline organizations.

Another limitation of the research is that a survey questionnaire was used to measure the independent and dependent variables. At the time of discussions it will be hard to get perfect responses due to the nature and the time constraint of the participants, and similarly it is hard to pay their full participation to answer the questionnaire while working at their duties. 
The current study did not much concentrate on demographic factors such as, gender, family background, and the marital status. According to the nature of the population and due to the nature of the industry when selecting variables, only select few selections as variables.

\section{Conclusion}

It was explored that employee welfare benefits constitutes the largest part of the employee retention process. An attractive employee benefit package plays a critical role in retaining the employees. This is very consistent with the famous theory on Maslow's hierarchy of needs, that certain employees or groups of employees are drawn largely to pecuniary gains and are less drawn to non-pecuniary benefits that an employment may offer.

The results of the current study show that employee welfare benefits signify an organization appreciation for employees' effort and this encourage individuals to retain with the firm (Kyndt, Dochy \& Moeyaert, 2009).

\section{References}

Ahmad, R., \& Scott, N. (2015). Fringe benefits and organisational commitment: the case of Langkawi hotels. Tourism review, 70(1), 13-23.

Jorens, Y., Gillis, D., Valcke, L., De Coninck, J., Devolder, A., \& De Coninck, M. (2015). Atypical forms of employment in the aviation sector', European social dialogue, European Commission, 2015.

Kossivi, B., Xu, M., \& Kalgora, B. (2016). Study on determining factors of employee retention. Open Journal of Social Sciences, 4(05), 261.

Kyndt, E., Dochy, F., Michielsen, M., \& Moeyaert, B. (2009). Employee retention: Organisational and personal perspectives. Vocations and Learning, 2(3), 195-215.

Mandhanya, Y. Compensation Policy a Tool; Fostering Employee Retention.

Mitchell, O. S. (1982). Fringe benefits and labor mobility. The Journal of Human Resources, 17(2), 286-298.

Premarathne, M. A. D. T., \& Perera, G. D. N. (2017, March). The Effect of Welfare Facilities on Employee Retention in a Selected Company in Sri Lanka. In Proceedings of International HR Conference (Vol. 2, No. 1). 
Suresha, B. (2007). Study on employee welfare measures in arignar anna sugar mills, Tanjore. 67-68.

Vidal-Salazar, M. D., Cordón-Pozo, E., \& de la Torre-Ruiz, J. M. (2016). Flexibility of benefit systems and firms' attraction and retention capacities. Employee Relations, 38(4), 487-504.

Weerasinghe, T. D., Batagoda, C. K., \& Nadeera, M. G. N. L. (2012). The Impact of Rewards on Retention of Workers: A Study of Operative Level Employees in the Apparel Industry. Jaffna University Annual Research Conference: Conference Proceedings.

Ahmad, R., \& Scott, N. (2015). Fringe benefits and organisational commitment: the case of Langkawi hotels. Tourism review, 70(1), 13-23. 